\title{
232. 認知域值検査時のニオイを表現する言葉についての検討
}

大城功也 - 米野邦彦 - 石橋陽二 · 大峡星夫 - 竹内 聡 -

梅田良三（金沢大）

T \& T OLFACTOMETER を用いた搝営検査での 検知域值の判定は，それが他覚的検查ではないにして も，かなり正確に行える。すなわち，もし䁔䀧な場合が

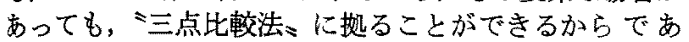
る.これに対して, 認知域值の判定は必ずしも容易では なく，検者としても確信が持てない場合も起ってくる。 すなわち，どのようなニオイであるかを実際には認知で きていても，それを言葉で表現することができない場合 がある。しかも，表現できたとしても，「良いニオイ」。 「悪いニオイ」などのごとく，漠然とした表現もあり， 検者の期待寸る回答がなかなか得られないことがある。 そこで認知域値も，上り正確に判定したいと考え，その 前段階として，(1)多用される（すぐに思い出せる）二オ イを表現する言葉について，(2)基準奥 5 種の認知が，実 際にはどのような言葉で表現されるかについての2 項目 の調查をした。

方法

(1)多用される（すぐに思い出せる）二オイを表現する
ニオイを表現する言葉（頻度順）

\begin{tabular}{|c|c|}
\hline $\begin{array}{l}\text { 1. }(41 \%) \text { トイレ } \\
\text { 2. }(38 \%) \text { 鹰敗真(C) } \\
\text { 3. }(27 \%) \text { 焦げくさい(B) } \\
\text { 4. }(23 \%) \text { 香 水 } \\
\text { 4. }(23 \%) \text { 花 } \\
\text { 4. (23\%) たばこ } \\
\text { 7. }(21 \%) \text { 汗くさい(C) } \\
\text { 8. }(19 \%) \text { ガ ス } \\
\text { 9. }(17 \%)=ン ニ ク ~ \\
\text { 9. }(17 \%) \text { 体 臭 } \\
\text { 1. (17\%) 酢 }\end{array}$ & 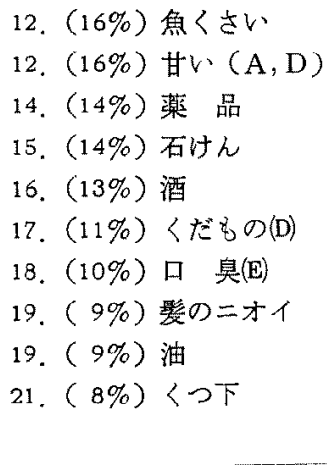 \\
\hline
\end{tabular}

$\%$; 対象 242 人中の回答率

(A)，(B) …... 基淮臭 5 種の二オイ言葉

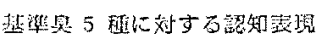

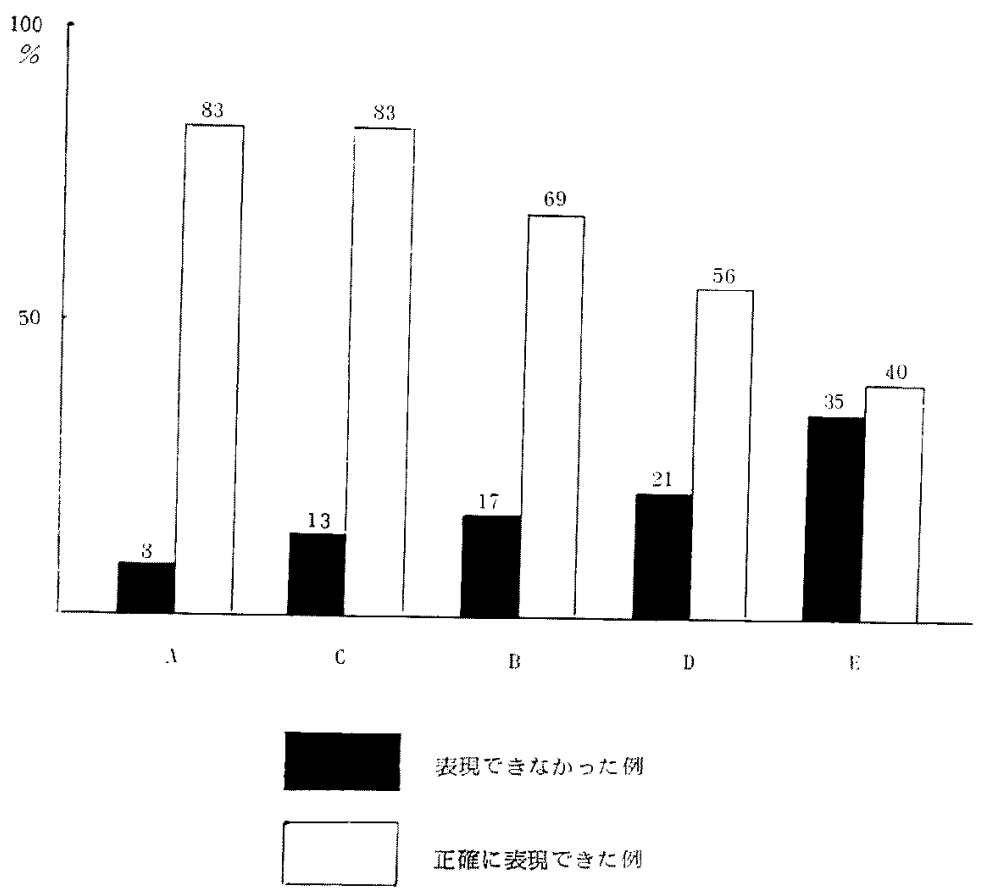


愛荣知るために，アンケート調查を行った。すなわ ら，全くヒントを与えることなしに、ニオイを表現する 言整をなる心く多く甾くように求めた，回答は梌者の立 ち会いのもとで畫いてもらい，時閒は便宜上5分以内に 制限した。対象は15藏以上の男 18 人, 女124人の計 242 人であった。

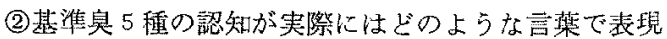
されるか防て，予め湘定した検知城值の 2 段階上の 瀼度により，ヒントを与えることなしに，「何の，ある いは何に似たニオイであるか」と問い，答えさせた，刘 象汢20歳台の男女52人であった。

\section{成績および結果}

(1)については，回答された言葉の個数には個人差があ り，最低1個から最高29個までさまざまであった，回答 された言葉の全てを平均すると，30歳までの人で 9 俔, 31 歳から50歳までの人で 7 個，そして51歳以上の人で 5 個であった。ニ才イを表現する言葉を䪽度順に示寸と表 のごとくであった，ただしこれは唐突もない表現は削除 してあり，42番目交でに生とめた一部である。これよ り，文部省嗅觉研究班が基準臭種について選定した言葉 は，大概20番目位东でに含宗机た。

(2)についてはどらしても認知高言葉で表現できなか った例，また対象者中，検者が適切な表現であると判断 した者（正確に表現できた例）を図示した。これより， 基淮臭は ACBDE の順に表現しやすく，A と C 老は しめとして，BDE の順に二オイを正しく言い表和す言 葉が思い浮汃ぶや小と教える。

それぞれの嗅素を，文部省嗅覚研究班で選定された表
現法と比烄し言及すると，嗅素Bにおいては，認知の表 現の判定に特に問題はないよ5に思われる。䑄素A $\mathrm{A} D$ の場合，文部省嗅覚研究班では，それぞれ「轻くて甘い ニオイ」「せくて重いニオイ」としているが，検者の䠰 查では，以ずれも「甘いニオイ」と共通の表現がなさ れ，被换者は「甘いニオイ」の区別はできなかった。 な 扮嗅菜ADともに良い二オイとも表現されたが，これ 区別することはむつかしいと侾えられる，懙素について 注，ADが快適なニオイに属するとすれば，CE忙不快 なニオイに属すると思われ，表現される带葉にも反映さ れる。そのため，CEは大体判定できるが，明確な区別 は前述の理由でむつかしいと考えられる。

\section{結語}

1. 基準宴種は，ヒントなしで得られたニオイを表現 する言菜の20番目位までに含まれた，故にルチンに使用 する嗅蕒として概2適切であると考えられる。

2. 基準臭種恃, ACBDE の覑に二オイを表現しや すく，正答しやすいと考えられる.

3. 基準臭種に刘する正答率の革均は66\%であった。

4. 検者の確信できる，より正確な認知城值の判定方 法功必要であると考えられる。

質問 梅田良三（金沢大）. 現在娭討中の，語表加ら， 被験者に選ばせる方法之，说前の方法上で差があるか。

店答この演題以前の検郡で，症例 42 例に，ヒントを 与えなかった場合の認知正常率は61\%，私共の考えた語 表を提示した場合のそれは92\%であった。しかし，前 者、娞者の域值に壮耉がないようだ。

(B 82-1219-32522)

233. 反復噴出性鼻出血とその止血.

\author{
（特に電気凝固）について
}

任伯修（東京都）

過去 3 年間の奥出血経験例は261名で, その内訳は與 子143名・女子118名，年閝的には10歳迄加最も多く, 以 後年龄の増加に伴って減少している（表1），又男女別 では総数として注男子が多いが，20歳・30歳代は逆に女 子の方が多い。平均月別分布では年間７月点頂点しして 6月から8月及び3月に最も多く発生している。

これらの症例の中茵粘膜深層の血管破綻によると思わ

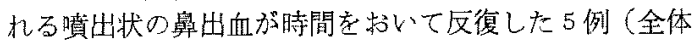
の1. 9\%)について報告すると其に，元の特異性と此伹 について考察存行った。

炡例 177 歳男性, 建管業. 出血部位左下番甲介内側 面後半部。数特閒の閒隔で 3 回出血. 最初の2 回法部位 不明. 3 回目に貲出状出血を目慗して位圆砝認。電気 凝固止血.

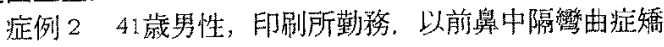

正手術を受け轒中隔前下方に小指頭大の穿孔。しばしば 病皮形成のため擤舅等によりその前縁附近から出血. 初

表 1

鮩出血患者の年令分布 (昭和51 53年)

\begin{tabular}{|c|c|c|c|c|c|c|c|c|c|}
\hline & $\begin{array}{c}0= \\
10 \text { 敞 }\end{array}$ & $\begin{array}{l}11 \sim \\
20 \text { 药 }\end{array}$ & $\begin{array}{l}21 \text { - } \\
30 \text { 䠞 }\end{array}$ & $\begin{array}{l}31- \\
40,1)\end{array}$ & $\begin{array}{l}41- \\
50 \mathrm{~d}\end{array}$ & 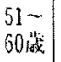 & 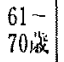 & $\begin{array}{l}\text { 71战 } \\
\text { 以.t. }\end{array}$ & \\
\hline$y$ & 93 & 20 & 8 & 6 & 5 & 5 & 4 & 2 & $\begin{array}{l}143 \hat{\lambda} \\
(54.8 \%)\end{array}$ \\
\hline th & 63 & 19 & 12 & 10 & 5 & 4 & 4 & 1 & $\begin{array}{l}11 \mathrm{~B} \text { 人 } \\
(45.2 \%)\end{array}$ \\
\hline 命部 & 156 & 39 & 20 & 16 & 10 & 9 & 8 & 3 & $261 人$ \\
\hline$\%$ & 59.8 & 14.9 & 7.7 & 6.1 & 3.8 & 3.4 & 3.1 & 1.1 & \\
\hline
\end{tabular}

